\title{
Is It Time to Abolish the Substance of EU Citizenship Rights Test?
}

\author{
Martijn van den Brink, Ph.D., LL.M. \\ British Academy Postdoctoral Fellow, University of Oxford, Oxford, UK \\ martijn.vandenbrink@politics.ox.ac.uk
}

\begin{abstract}
It is almost ten years since Ruiz Zambrano decided that Article 20 TFEU precludes national measures which deprive EU citizens of the genuine enjoyment of the substance of their citizenship rights. The CJEU has since then clarified when the substance of rights test applies. This article highlights several inconsistencies and unresolved puzzles in the case law. First, contrary to what was initially suggested, EU citizens can be deprived of the substance of their rights. Second, contrary to what initial judgments suggested, the substance of rights test is not independent of but grounded in the right to free movement. This suggests that the same level of protection can be provided to EU citizens without this test, simply by relying on EU free movement law. The paper concludes by suggesting that these deficiencies can only be resolved by reconsidering the substance of rights test altogether.
\end{abstract}

\section{Keywords}

EU citizenship - Ruiz Zambrano - substance of rights - Article 20 TFEU

\section{$1 \quad$ Introduction}

It is almost ten years since the Court of Justice of the European Union (CJEU) decided that Article 20 TFEU 'precludes national measures which have the effect of depriving citizens of the Union of the genuine enjoyment of the substance of the rights conferred by virtue of their status as citizens of 
the Union.' Ruiz Zambrano counts as one of the most controversial cases the CJEU delivered in the previous decade. Hailed by some as the first step on the way towards a full-fledged citizenship of the European Union and criticised by others as another example of the Court overstepping the limits of legitimacy, there has not been a shortage of academic discussion of the decision. ${ }^{2}$ This article is interested in what has become of the 'substance of rights test'. Much was uncertain after Ruiz Zambrano was decided, but the Court has developed an important line of cases clarifying when the substance of rights test applies. A previous paper of mine questioned the added value of this test. ${ }^{3}$ This article will take stock of the relevant case law, in particular recent developments, to evaluate whether the scepticism expressed in the initial paper was justified. Can we make sense of the substance of rights test ten years on?

Section 2 offers a brief overview of important legal developments since Ruiz Zambrano showing that the prime beneficiaries of the substance of rights test are children with a relationship of dependence to a third-country national. Subsequently, the article addresses certain inconsistencies and unresolved puzzles in the CJEU's reasoning. Section 3 will explain that, contrary to what the Court initially appeared to suggest, EU citizens can be deprived of the genuine enjoyment of the substance of their rights. Section 4 shows that, contrary to what the Court used to suggest, the substance of rights test is not independent from but grounded in the right to move and reside freely within the

1 Case C-34/o9 Ruiz Zambrano, EU:C:2011:124, para 42.

2 Among the positive assessments we find, Dimitry Kochenov, 'A Real European Citizenship; A New Jurisdiction Test; A Novel Chapter in the Development of the Union in Europe', (2011) 18 Columbia Journal of European law, 55; Dimitry Kochenov and Sir Richard Plender, 'EU Citizenship: From an Incipient Form to an Incipient Substance? The Discovery of the Treaty Text', (2012) 37 European Law Review, 369; Michaela Hailbronner and Sara Iglesias Sánchez, 'European Court of Justice and Citizenship of the European Union: New Developments towards a Truly Fundamental Status', (2011) 5 Vienna J. on Int'l Const. L., 498; Hanneke van Eijken and Sybe de Vries, 'A New Route Into the Promised Land? Being a European Citizen After Ruiz Zambrano', (2011) 5 European Law Review, 704; Armin Von Bogdandy and others, 'Reverse Solange - Protecting the Essence of Fundamental Rights against EU Member States', (2012) 49 Common Market Law Review, 489. The more critical scholarship includes, Niamh Nic Shuibhne, 'Seven Questions for Seven Paragraphs', (2011) 2 European Law Review, 161; Kay Hailbronner and Daniel Thym, 'Note on Ruiz Zambrano', (2011) 48 Common Market Law Review, 1253; Bruno de Witte, 'Democratic Adjudication in Europe - How Can the European Court of Justice Be Responsive to the Citizens?', in: Michael Dougan, Niamh Nic Shuibhne and Eleanor Spaventa (eds), Empowerment and disempowerment of the European citizen (Hart Publishing 2012), 138.

3 Martijn van den Brink, "The Origins and the Potential Federalising Effects of the Substance of Rights Test', in: Dimitry Kochenov (ed), EU Citizenship and Federalism: The Role of Rights (Cambridge University Press 2018), 85 . 
Member States. Hence, it is suggested that the same level of protection can be conferred on EU citizens without this test, simply by relying on EU free movement law. By way of conclusion, Section 5 considers ways to resolve these deficiencies, but suggests that there are none for as long as the Court is unwilling to address its problems of legal reasoning head on and reconsider its post-Ruiz Zambrano case law altogether.

Ruiz Zambrano builds on the case of Rottmann, in which the CJEU decided that a decision to withdraw an individual of his or her Member State nationality falls 'by reason of its nature and its consequences, within the ambit of European Union law', if such a deprivation also strips the national of the status and rights of EU citizenship 'conferred by Article [20 TFEU].4 According to the Court in Ruiz Zambrano, that Article 20 TFEU precludes not just measures that would deprive Member State nationals of the status of EU citizenship but also the genuine enjoyment of the substance of rights they enjoy by virtue of their status as EU citizens. ${ }^{5}$ The revolutionary nature of Ruiz Zambrano and Rottmann resides in their extension of the scope of EU law. ${ }^{6}$ EU citizens traditionally only fell within its scope if they had exercised the right to move and reside freely. ${ }^{7}$ Hitherto, third country nationals could only derive a residence right when their EU citizen family member exercised her right of free movement and residence. They could on the ground that citizens would be unwilling to exercise their free movement rights derived from art. 21 TFEU and Directive 2004/38 if they could not bring their family along to the new state of residence: protecting family life was necessary 'in order to eliminate obstacles to the exercise of the fundamental freedoms guaranteed by the [Treaties]. ${ }^{8}$ Without such a 'cross-border connection', their situation was governed by the laws of their Member State of residence. In Rottmann and Ruiz Zambrano, the Court proved willing to protect the status of and rights conferred on EU citizens in situations

4 Case C-135/o8 Rottmann, EU:C:2010:104, para 42.

5 Ruiz Zambrano (n 1), para 42. Read Case C-165/14 Rendón Marín, Opinion of ag Szpunar, EU:C:2016:75, for a useful discussion of the relation between Rottmann and Ruiz Zambrano.

6 Kochenov, 'A Real European Citizenship; A New Jurisdiction Test; A Novel Chapter in the Development of the Union in Europe' (n 2); Hailbronner and Thym (n 2).

7 There have of course always been rights that apply in situations that are purely internal to a Member State. Section 4 will briefly discuss some such rights.

8 E.g. Case C-127/o8 Metock, EU:C:2008:449, para 56; Case C-6o/oo Carpenter, EU:C:2002:434, para 38; Case C-459/99 MRAX, EU:C:2002:461, para 53. Art. 21 TFEU en Dir. 2004/38. 
lacking a cross-border element. Ruiz Zambrano added a layer of protection by deciding that third country nationals with dependent minor children who are EU citizens enjoy a derived right of residence also when the children had not exercised their free movement rights. To refuse this would require the children 'to leave the territory of the Union in order to accompany their parents' and deprive them of the ability 'to exercise the substance of the rights conferred on them by virtue of their status as citizens of the Union'. ${ }^{9}$

However, because the Court failed to clarify the scope of its decision, it was unclear whether the substance of rights test would be confined to the facts in Ruiz Zambrano or apply to a much wider set of situations. Some speculated that the Court would be willing to use EU citizenship not just to protect the right to family life but as an additional vehicle for the protection of all fundamental rights..$^{10}$ Others hoped that the decision would lead the Court to reconsider its cross-border requirement altogether and bring an end to the much-maligned phenomenon of reverse discrimination. ${ }^{11}$ This was not to be. The decisions immediately following Ruiz Zambrano clarified that the substance of rights test was limited in scope. It offers a derived right of residence to third country nationals in specific circumstances that are similar to the facts at issue in Ruiz Zambrano. Dereci affirmed that 'the denial of the genuine enjoyment of the substance of the rights ... refers to situations in which the Union citizen has, in fact, to leave the territory of the Union as a whole.12 Underlining the restrictive nature of the substance of rights test, the Court added that it was not sufficient that 'it might appear desirable to a national of a Member State, for economic reasons or in order to keep his family together in the territory of the Union.' ${ }^{\prime 3}$ Instead, the Court clarified in K.A. and others, it is required that there

$9 \quad$ Ruiz Zambrano (n 1) para 44.

10 Hailbronner and Sánchez (n 2); Van Eijken and De Vries (n 2); Van den Brink (n 3); Von Bogdandy and others (n 2). For a critical perspective on connecting EU citizenship with fundamental rights, Martijn van den Brink, 'EU Citizenship and (Fundamental) Rights: Empirical, Normative, and Conceptual Problems', (2019) 25 European Law Journal, 21.

11 See in particular, Case C-34/og Ruiz Zambrano, EU:C:2011:124, Opinion of AG Sharpston. For further criticism of reverse discrimination, Camille Dautricourt and Sebastien Thomas, 'Reverse Discrimination and Free Movement of Persons under Community Law: All for Ulysses, Nothing for Penelope?', (2009) 34 European Law Review, 433; Sara Iglesias Sánchez, 'Purely Internal Situations and the Limits of EU Law: A Consolidated Case Law or a Notion to Be Abandoned?', (2018) 14 European Constitutional Law Review, 7; Hester Kroeze, 'Distinguishing Between Use and Abuse of EU Free Movement Law: Evaluating Use of the "Europe-Route" for Family Reunification to Overcome Reverse Discrimination', (2018) 3 European Papers, 1209.

12 Case C-256/11 Dereci, EU:C:2011:734, para 66. See also, Case C-434/o9 McCarthy, EU:C:2011:277, para 5 .

13 Ibid., para 68. 
is 'a relationship of dependency [that] would lead to the Union citizen being compelled to accompany the third-country national and leave the territory of the EU.'.14

When does such a relationship of dependency arise? The Court has deemed it necessary to draw a distinction between adults and children. Adults can derive a right of residence from Article $20 \mathrm{TFEU}$ 'only in exceptional cases, where, having regard to all the relevant circumstances, there could be no form of separation of the individual concerned from the member of his family on whom he is dependent.'. ${ }^{15}$ The reason is that they are 'as a general rule, capable of living an independent existence apart from the members of his family'16 It would be conceivable that third country nationals caring for adult EU citizens with serious disabilities could derive a right of residence. ${ }^{17}$ However, 'the existence of a family link, whether natural or legal ... cannot be sufficient ground to justify the grant ... of a derived right of residence.' ${ }^{18}$ A relationship of financial dependency certainly is insufficient to activate the substance of rights test. ${ }^{19}$ That is to say, adults will be denied a derived right of residence in all but the most extraordinary circumstances.

The situation is different for third country nationals with a relationship of dependency to children. As a general rule, it is important to define 'which parent is the primary carer of the child and whether there is in fact a relationship of dependency between the child and the third-country national parent'.20 As van Eijken and Phoa have observed with respect to the relevant case law, 'de facto dependency is far more important than formal relationships between the primary carer and the EU citizen. ${ }^{21}$ According to $O$ and others, the application of the substance of rights test is not 'confined to situations in which there is a blood relationship between the third country national for whom a right of residence is sought and the Union citizen who is a minor from whom that

\footnotetext{
14 Case C-82/16 K.A. and others, EU:C:2018:308, para 52 (italics mine).

15 Ibid.

16 Ibid., para 65 .

17 Hester Kroeze, 'The Substance of Rights: New Pieces of the Ruiz Zambrano Puzzle', (2019) 44 European Law Review, 238, 244.

18 K.A. and others (n 11), para 75; Case C-836/18 Subdelegación del Gobierno, EU:C:2O20:119, para 58.

19 K.A. and others (n 11), para 68.

$20 \quad$ Case C-133/15 Chavez Vilchez, EU:C:2017:354, para 70.

21 Hanneke van Eijken and Pauline Phoa, 'The Scope of Article 20 TFEU Clarified in Chavez-Vilchez: Are the Fundamental Rights of Minor EU Citizens Coming of Age?', (2018) 43 European Law Review, 649, 955.
} 
right of residence might be derived'.22 Instead, national authorities must take consideration of different factors as listed in Chavez-Vilchez. It is relevant but not sufficient 'that the other parent, a Union citizen, is actually able and willing to assume sole responsibility for the primary day-to-day care of the child.' ${ }^{23}$ In addition,

account must be taken, in the best interests of the child concerned, of all the specific circumstances, including the age of the child, the child's physical and emotional development, the extent of his emotional ties both to the Union citizen parent and to the third-country national parent, and the risks which separation from the latter might entail for that child's equilibrium. ${ }^{24}$

If the examination of these factors indicate that a relationship of dependency exists, the third country national enjoys a derived right of residence in order to prevent that the Union citizen 'would be compelled to leave the territory of the European Union as a whole and thereby deprived of the genuine enjoyment of the substance of the rights conferred on him by [Article $20 \mathrm{TFEU}]^{\prime} .25$

The substance of rights test offers a residual ground for protecting the rights of EU citizens in case no other ground is to their avail. ${ }^{26}$ The Court asks first whether Article 21 TFEU and Directive 2004/38 apply. ${ }^{27}$ The Directive applies only to EU citizens 'who move to or reside in a Member State other than that of which they are a national'.28 Citizens returning to their Member State of nationality enjoy protection under the right to free movement and residence laid down in Article 21 TFEU as well. However, as the Directive applies by analogy in those cases, ${ }^{29}$ all third country national family members of mobile EU citizens enjoy a derived right of residence when necessary 'to ensure that a

22 Joined Cases C-356/11 and C-357/11 O and S v Maahanmuuttovirasto, EU:C:2012:776, para 55 .

23 Chavez Vilchez (n 19), para 71.

24 Ibid.

$25 \quad$ Ibid., para 72.

26 Van Eijken and Phoa (n 21), 967; Kroeze (n 17), 241.

27 Case C-165/14 Rendón Marín, EU:C:2016:675, para 35; Chavez Vilchez (n 19), para 49. See further, Päivi Johanna Neuvonen, 'EU Citizenship and Its "Very Specific” Essence: Rendón Marin and CS', (2017) 54 Common Market Law Review, 1201; Van Eijken and Phoa (n 21); Kroeze (n 17).

28 Article 3(1) of Directive 2004/38/EC. See also, Case C-457/12, S and G, EU:C:2014:136, para 34; Chavez-Vilchez (n 19), para 53.

29 Case C-456/12, O and B, EU:C:2014:135, para 50; Chavez-Vilchez (n 19), para 54. 
Union citizen can exercise effectively his rights to move and reside freely'.30 Second, when there is no cross-border movement and the conditions for the application of Article $21 \mathrm{TFEU}$ and Directive 2004/38 are not fulfilled, the Court asks whether a derived right of residence can be founded on Article $20 \mathrm{TFEU}$, on the ground that such a right is necessary to prevent depriving EU citizens of the genuine enjoyment of the substance of their rights.

The substance of rights test has not served as a vehicle for the protection of all fundamental rights or brought an end to the much-maligned phenomenon of reverse discrimination. However, while not as revolutionary as some had hoped, the Court still presents Article $20 \mathrm{TFEU}$ as an additional source of rights for EU citizens, supplemental to Article 21 T FEU and the Citizenship Directive. The following sections contest this view by illustrating that the substance of rights test is virtually redundant and the distinction drawn between Articles 20 and 21 TFEU arbitrary. The right of residence EU citizens can derive under Article $20 \mathrm{TFEU}$ is subject to the same conditions as the rights under Article 21 TFEU and could be protected in its entirety by the right to move and reside freely laid down in Article $21 \mathrm{TFEU}$. Therefore, it is suggested that a sounder approach to EU citizenship would end the practice of treating Articles 20 and $21 \mathrm{TFEU}$ as distinct grounds from which third country nationals can derive a right to residence.

\section{3}

\section{The Conditionality of the Substance of EU Citizenship Rights}

The Court initially presented the prohibition to deprive EU citizens of the genuine enjoyment of the substance of their rights in absolute terms. Ruiz Zambrano stated that Article 20 TFEU precludes national measures which have such an effect without qualification and the first cases thereafter continued to present the test in such terms. At the same time, however, it began to accept that EU citizens can actually be deprived of the substance of the rights they enjoy as EU citizens, ${ }^{31}$ thereby weakening the value of Article 20 TFEU relative to Article $21 \mathrm{TFEU}$. In fact, as the following discussion of the relevant case law shows, the conditions under which third country nationals can be denied a derived right of residence is the same under Articles 20 and 21 TFEU.

The assumption of the Article 20 TFEU doctrine is that EU citizens cannot be deprived of the genuine enjoyment of the substance of rights. Rottmann supports this observation by limiting the Member State's competence in

$30 \quad$ Rendón Marín (n 26), para 36.

31 On this matter, read also Opinion of AG Szpunar ( $n$ 5), paras 123-133. 
nationality law by restricting the situations in which nationality, and therewith, the enjoyment of rights of EU Citizenship are withdrawn. According to established case law, 'it is for each Member State, having due regard to EU law, to lay down the conditions for the acquisition and loss of nationality'. ${ }^{32}$ The proviso 'having due regard to EU law' was interpreted in Rottmann as bringing an EU citizen placed 'in a position capable of causing him to lose the status conferred by [Article $20 \mathrm{TFEU}$ ] and the rights attaching thereto ... within the ambit of European Union law'.33 Individuals who are deprived of their status as EU citizen will be deprived of the substance of the rights they enjoy by virtue of this status. However, while Rottmann shows some intention to protect EU citizens against arbitrary loss of this status and the rights attaching thereto, it also illustrates that the right to the genuine enjoyment of the substance of EU citizenship rights is a conditional right. Member States can still deprive individuals from their nationality and, by extension, their EU citizenship and the genuine enjoyment of the substance of their rights if such decisions observe the principle of proportionality. ${ }^{34}$ In Tjebbes, the Court provided more detailed information about the requirements of the proportionality assessment to be conducted. It requires 'an individual assessment of the situation of the person concerned and that of his or her family, ${ }^{35}$ to see whether the national measures 'disproportionately affect the normal development of [the citizen's] family and professional life from the point of view of EU law' ${ }^{36}$ In conducting such an analysis, account must be had of 'the fundamental rights guaranteed by the Charter $[\ldots]$ and specifically the right to respect for family life $[\ldots]$ read in conjunction with the obligation to take into consideration the best interests of the child'. ${ }^{37}$

32 Case C-369/9o Micheletti, EU:C:1992:295, para 10; Case C-200/02 Zhu and Chen, EU:C:2004:639, para. 37 .

33 Rottmann (n 5) para 42. See further, Dimitry Kochenov, 'Case C-135/o8, Janko Rottmann v. Freistaat Bayern, Judgment of the Court (Grand Chamber) of 2 March 2010', (2010) 47 Common Market Law Review, 1831.

34 Ibid., para 55 .

35 Case C-221/17 Tjebbes, EU:C:2019:189, para 44. For further discussion, Hanneke van Eijken, 'Tjebbes in Wonderland: On European Citizenship, Nationality and Fundamental Rights: ECJ 12 March 2019, Case C-221/17, M.G. Tjebbes and Others v Minister van Buitenlandse Zaken, EU:C:2019:189', (2019) 15 European Constitutional Law Review, 714; Dimitry Kochenov, 'The Tjebbes Fail', (2019) 4 European Papers, 319; Martijn van den Brink, 'Bold, but Without Justification? Tjebbes', (2019) 4 European Papers, 409; Peter Van Elsuwege and Hester Kroeze, 'Het Arrest Tjebbes: De Evenredigheidstoets Als Complexe Brug Tussen Nationaliteitswetgeving En Unieburgerschap', (2019) 5-6 Nederlands Tijdschrift voor Europees Recht, 166.

$36 \quad$ Ibid.

37 Ibid., para 45 . 
While restricting Member States' power to withdraw EU citizenship from its citizens via denaturalisation, both decisions also illustrate that EU citizenship can legitimately be withdrawn and the substance of the rights attaching to this status be balanced away. We know that nationals from a withdrawing Member State lose their EU citizenship once the country has officially withdrawn..$^{38}$ Rottmann and Tjebbes demonstrate that loss of EU citizenships and the rights attached thereto can also be legitimate in individual cases. The Bundesverwaltungsgericht that referred the preliminary reference in Rottmann decided that the decision to withdraw Mr Rottmann's German nationality was proportionate. ${ }^{39}$ Due to the seriousness of the offence committed and the relatively short time between naturalisation and the withdrawal of German nationality, the German public interest outweighed the negative consequences such a decision would entail for Mr Rottmann. ${ }^{40} \mathrm{Mr}$ Rottmann was rendered stateless and lost his status as EU citizen and the substance of the rights attaching thereto.

In the meantime, the Court has clarified that the right of residence EU citizens can derive from Article $20 \mathrm{TFEU}$ in order to protect the substance of their EU citizenship rights is not absolute either. In Subdelegación del Gobierno, the latest decision clarifying Ruiz Zambrano so far, the Court said explicitly that 'the derived right of residence under Article 20 TFEU is not absolute', ${ }^{11}$ but earlier it had already decided that 'Article 20 TFEU does not affect the possibility of Member States relying on an exception linked, in particular, to upholding the requirements of public policy and safeguarding public security' ${ }^{42}$ Such derogations must be interpreted strictly and in accordance with the principle of proportionality, ${ }^{43}$ but the refusal of the right of residence can be justified on the grounds of public policy and public security even if the effect 'is that the Union citizen who is a family member of that third-country national is compelled to leave the territory of the European Union: 44 Importantly, the public policy and security exceptions that Member States can rely on to restrict the

38 Elsewhere I explain that arguments to the contrary have never been convincing. Martijn van den Brink and Dimitry Kochenov, 'Against Associate EU Citizenship', (2019) 57(6) Journal of Common Market Studies, 1366.

39 For a more detailed discussion of the application of the principle of proportionality by the CJEU and the Bundesverwaltungsgericht read, Nathan Cambien, 'Case C-135/o8, Janko Rottmann v. Freistaat Bayern', (2011) 17 Columbia Journal of European Law, 375, 386-392. BVerwG 5 C 12.10 (2010), para 36.

41 Subdelegación del Gobierno (n 19), para 43.

42 Case C-304/14 CS, EU:C:2016:674, para 36; Rendón Marín (n 26), para 81; K.A. and others (n 14), para 9o.

$43 \quad$ K.A. and others (n 14), paras 91-93.

$44 \quad$ Ibid., para 92. 
right of residence EU citizens can derive under Article $20 \mathrm{TFEU}$ are exactly the same as those for the residence rights they enjoy under Directive 2004/38 and Article 21 TFEU. ${ }^{45}$ In this respect, no meaningful difference exists between, on the one hand, Article 21 TFEU and the Citizenship Directive and, on the other hand, Article 20 TFEU. National authorities can invoke the same grounds to deny third country nationals a derived right of residence, irrespective of whether this would deprive citizens of the right to move and reside freely or the genuine enjoyment of the substance of their rights.

The fact that the substance of rights test offers a conditional right that can be restricted for the same set of public policy and security reasons as EU citizens' right to free movement is insufficient to conclude that the distinction between Articles 20 and $21 \mathrm{TFEU}$ is contrived. After all, it could still be that, while the prohibition to deprive EU citizens of the genuine enjoyment of the substance of their rights is not absolute, Article 20 TFEU protects EU citizens and their third country national relatives in ways that could not be realised under Article 21 TFEU. This section will challenge this idea by showing that the substance of rights test offers nothing that could not be offered by Article 21 TFEU.

Remember that the Court uses Article $20 \mathrm{TFEU}$ as a residual provision in 'very specific situations [when] the Union citizen concerned has not made use of his freedom of movement'. 46 Its residual nature suggests that Article 20 TFEU is used to protect EU citizens against deprivations of their rights in situations in which Article $21 \mathrm{TFEU}$ could not be applied, for it would be odd to use Article $20 \mathrm{TFEU}$ as a supplemental source of rights protection if the same result could be achieved by applying Article $21 \mathrm{TFEU}$. Indeed, immediately after Ruiz Zambrano, the Court suggested that the substance of the rights associated with the status of EU citizenship was distinct from the right to move and reside freely. In McCarthy, it stated that national measures could have the effect of depriving EU citizens 'of the genuine enjoyment of the substance of the rights associated with her status as a Union citizen, or of impeding the exercise of her right to move and reside freely within the territory of the Member States.47

$45 \quad$ Kroeze (n 17), 249.

$46 \quad$ CS (n 41), para 29; Rendón Marín (n 26), para 74.

47 Case C-434/og McCarthy, EU:C:2011:277, para 49. For further reflection on the distinction this case draws between Articles 20 and 21 TFEU, Peter Van Elsuwege, 'Court of Justice of 
In other words, an impediment of the right to move and reside freely is captured by Article 21 TFEU and a deprivation of the genuine enjoyment of the substance of citizenship rights by Article 20 TFEU.

While both provisions guarantee the right to move and reside freely, Article $20 \mathrm{TFEU}$ is more comprehensive in two respects. First, Article 20(1) TFEU confers on Member State nationals the status of EU citizenship: "[e]very person holding the nationality of a Member State shall be a citizen of the Union'. In this respect, it is logical that the Court relied on Article 20 TFEU in Rottmann and Tjebbes in order to assess the legitimacy of the withdrawal of EU citizenship status. Second, Article 2O(2) TFEU lists not just the right to free movement and residence but all EU citizenship rights: 'They shall have, inter alia,

(a) the right to move and reside freely within the territory of the Member States;

(b) the right to vote and to stand as candidates in elections to the European Parliament and in municipal elections in their Member State of residence, under the same conditions as nationals of that State;

(c) the right to enjoy, in the territory of a third country in which the Member State of which they are nationals is not represented, the protection of the diplomatic and consular authorities of any Member State on the same conditions as the nationals of that State;

(d) the right to petition the European Parliament, to apply to the European Ombudsman, and to address the institutions and advisory bodies of the Union in any of the Treaty languages and to obtain a reply in the same language.'

Given that Article $20 \mathrm{TFEU}$ is the residual provision, and the right to move and reside freely (Article $20(2)(\mathrm{a}) \mathrm{TFEU}$ ) already protected by Article $21 \mathrm{TFEU}$, perhaps the Court meant that the substance of rights test would apply to the rights listed in Article $2 \mathrm{O}(2)(\mathrm{b}-\mathrm{d}) \mathrm{TFEU}$ ?

The problem of this argument is that these rights are not obvious candidates for inclusion in the substance of rights test. ${ }^{48}$ The political and diplomatic rights listed in Article 2O(2)(b-d) TFEU enjoy protection under Articles 22-24 TFEU as well, so they do not benefit from the supplementary protection offered by the substance of rights test under Article 20 TFEU. This is even more so because the substance of rights test only tackles deprivations of the substance

the European Union European Union Citizenship and the Purely Internal Rule Revisited Decision of 5 May 2011, Case C-434/og Shirley McCarthy v. Secretary of State for the Home Department', (2011) 7 European Constitutional Law Review, 308. 
of citizenship rights, while one would expect that national measures impeding but not fully depriving citizens of the opportunity to exercise their political and diplomatic rights could be challenged as well, if not under Article $20(2)$ (b-d) TFEU then at least under Articles 22-24 TFEU. ${ }^{49}$ The substance of rights test thus adds nothing in terms of protection as far as the political and diplomatic rights EU citizens is concerned. Therefore, if neither the right to move and reside freely listed in Article $20(2)$ (a) nor those rights laid down in (b-d) benefit from inclusion in the substance of rights test, it would be difficult to make sense of this test if limited to the rights provided for in Article 2O(2) TFEU.

Yet this is what has become of Ruiz Zambrano in the most recent case law. The CJEu has clearly followed the reasoning of its President, who first said that 'Ruiz Zambrano is limited to cases where a national measure produces a de facto deprivation of one of the rights listed in Article 20(2) TFEU, 50 and later that it 'only concerned the freedom of movement of an EU citizen'.51 Likewise, the Court clarified that the purpose and justification of the derived rights of residence that arise under Article 20 TFEU 'are based on the fact that a refusal to allow them would be such as to interfere with a Union citizen's freedom of movement'.52 So it appears that the legal situation is currently at follows: Article 21 TFEU confers a derived right of residence when EU citizens have used the right to free movement. When they have not, Article 20 TFEU confers a right to avoid that citizens' right to free movement is restricted by virtue of them being forced to leave the EU.

This reading is unpersuasive and raises at least four questions. First, Articles $20(2)($ a) TFEU and 21 TFEU both confer on EU citizens 'the right to move and reside freely within the territory of the Member States'. Given the textual similarity of both provisions, on what ground could the Court have concluded that Article 20 TFEU offers a residual basis, above and beyond Article 21

49 For relevant case law on EU citizens' political rights, Case C-300/04 Eman and Sevinger, EU:C:2006:545; Case C-65o/13, Delvigne, EU:C:2015:648. For further discussion, Federico Fabbrini, 'The Political Side of EU Citizenship in the Context of EU Federalism', in: Dimitry Kochenov (ed), EU Citizenship and Federalism: The Role of Rights (Cambridge University Press 2017), 286.

$5^{\circ}$ Koen Lenaerts, "Civis Europaeus Sum": From the Cross-Border Link to the Status of Citizen of the Union', in: Pernilla Lindh and others (eds), Constitutionalising the EU judicial systems: essays in honour of Pernilla Lindh (Hart Publishing 2012), 231.

51 Koen Lenaerts and José A Gutiérrez-Fons, 'Epilogue on EU Citizenship: Hopes and Fears', in:Dimitry Kochenov (ed), EU Citizenship and Federalism: The Role of Rights (Cambridge University Press 2017), 765 .

52 CS (n 41), para 28; Rendón Marín (n 26), para 73; K.A. and others (n 14), para 5o; Subdelegación del Gobierno (n 19), para 38. 
TFEU, for the protection of the right to move and reside freely? Second, how do recent decisions that fuse the substance of EU citizenship rights with the right to move and reside freely stand in relation to McCarthy in which a clear distinction was drawn between free movement rights and the substance of rights test?53 To my knowledge, the Court never addressed this inconsistency. Third, the right to free movement laid down in Article 21 TFEU is according to established case law triggered not just when citizens exercise this right but also when a national measure is 'liable to hamper the exercise of the right'.54 If so, why would the Court need to rely on Article $20 \mathrm{TFEU}$ to challenge national measures that compel EU citizens to leave EU territory? If the CJEU genuinely believes that, by compelling citizens to leave EU territory, Member States are liable to hamper the exercise of the right to free movement, there is no reason to deny the application of Article 21 TFEU and apply Article 20 TFEU as a residual right. In other words, the distinction between Articles 20 and 21 TFEU is ostensibly as inexplicable as it is unnecessary. But finally, which contribution to free movement do Ruiz Zambrano and its progeny make? In what sense are EU citizens restricted in their free movement rights by being forced to leave the EU? At best, free movement was a purely hypothetical prospect in the Ruiz Zambrano line of cases. Hence the question: how do we square these decisions with the established legal principle that 'the purely hypothetical prospect of exercising the right of freedom of movement does not establish a sufficient connection with European Union law'?55 Even more problematic, freedom of movement was arguably not at stake at all, not even hypothetically. By virtue of their status as EU citizens, children are in a position to return and exercise their rights as EU citizens when they have grown older. ${ }^{56}$ So not just the distinction drawn between Articles 20 and 21 TFEU but also the attempt to ground Ruiz Zambrano in free movement is problematic. All things considered together, it is difficult to make sense of the substance of rights test when it is restricted to the right to move and reside freely, as well as when it is disconnected thereof.

EU citizens shall have 'inter alia' the rights mentioned in Article 2O(2) TFEU. Given that it is unconvincing to limit the substance of rights test to the rights

\footnotetext{
$53 \quad$ McCarthy (n 47), para 49.

54 Case C-353/o6 Grunkin and Paul, EU:C:2008:559, 22; Case C-208/og Sayn-Wittgenstein, EU:C:2010:806, para 54. See also, Case C-148/o2 Garcia Avello, EU:C:2003:539.

55 Case C-40/11 Iida, EU:C:2012:691, para 77; Case C-299/95 Kremzow, EU:C:1997:254, para 16; Case C-18o/83 Moser, EU:C:1984:233, para 18.

56 Provided they do not lose their nationality of an EU Member State after multiple years abroad as a result of nationals rules on the acquisition and loss of nationality. See Tjebbes (n 35).
} 
listed there, one possibility would be that it protects other rights not expressly mentioned, but such a reading finds no support in the relevant case law. It seems settled by now that a deprivation of fundamental rights does not trigger Article $20 \mathrm{TFEU}$. The Court has never reconsidered its position that an assessment regarding the substance of rights test is independent of and 'without prejudice to the question whether' there has been a violation of 'provisions on the protection of fundamental rights which are applicable in each case. ${ }^{57}$ In Chavez-Vilchez, the Court mentioned respect for the fundamental right to a family life in the context the substance of EU citizens' rights, ${ }^{58}$ but only to emphasise that national authorities' assessment of the relationship of dependency should be conducted with respect for this fundamental right. There is no indication that the Court meant to say that 'a violation of a Charter right - the right to family life read in conjunction with the obligation to respect the child's best interests - causes a violation of Art. 20 TFEU in itself'. ${ }^{99}$ More likely is it that the Court meant that the evaluation of the relationship of dependency should not produce an outcome that violates the fundamental right to family life. In other words, there is no indication that fundamental rights belong to the substance of EU citizenship rights and it might be better to keep things this way. As explained elsewhere, the concepts of citizenship and fundamental rights should be regarded as empirically, conceptually, and normatively distinct. ${ }^{60}$

Ten years after Ruiz Zambrano, it remains difficult to make sense of the substance of rights test. The Court has produced a whole body of decisions that is meant to clarify when the test applies, but the critical reader cannot escape the conclusion that its ambition to reign in the potential for radical interpretations has come at the expense of consistency and sound legal reasoning. The Court insists on a residual derived right of residence under Article 20 TFEU that is distinct from the right of residence that is derivative from the right to move and reside freely laid down in Article $21 \mathrm{TFEU}$. In the meantime, it grounds this residual right of residence in the right to free movement and makes it

Dereci (n 12), para 69; $O$ and $S$ (n 20), para 59. See also, Van Eijken and Phoa (n 21) 957; Fulvia Staiano, 'Derivative Residence Rights for Parents of Union Citizen Children under Article 20 Tf Eu: Chavez-Vilchez', (2018) 55 Common Market Law Review, 225, 233-234.

58 Chavez-Vilchez (n 19), para 70.

59 Van Eijken and Phoa (n 21) 958-959.

6o Van den Brink (n 10). 
subject to the same public policy and public security conditions that apply to the right to free movement under Article 21 TFEU. Put simply, if the Ruiz Zambrano line of cases is meant to safeguard EU citizens' right to move and reside freely, Article $21 \mathrm{TFEU}$ would have sufficed as the legal basis, even more so when the public policy and security limitations that apply to Article $21 \mathrm{TFEU}$ also apply to Article $20 \mathrm{TFEU}$. Yet if protecting free movement is the goal, the case law seems inconsistent with the established legal principle that the purely hypothetical prospect of exercising this right is insufficient to bring a situation within the scope of EU law. That the applicants in Ruiz Zambrani and later cases would exercise their right to free movement was hypothetical at best. It is not even clear that this right was at stake at all. Therefore, it remains unclear which contribution the substance of rights test makes to protecting the right to move and reside freely beyond the protection of Article $21 \mathrm{TFEU}$.

Is there a plausible way out of this legal jumble? Possibly, but not for as long as the Court is unwilling to reconsider its post Ruiz Zambrano case law altogether. For a start, it should realise and acknowledge that the distinction between Article 20 and 21 TFEU is fabricated. Of course, Article 20 TFEU confers the status of EU citizenship and a number of rights attached thereto that Article 21 TFEU does not, but as explained, none of the rights listed in the latter provision benefit from the residual protection offered by the substance of rights test. Moreover, for as long as the sole purpose of protecting citizens against deprivations of the genuine enjoyment of the substance of rights is protecting citizens against interferences with their right to move and reside freely, it is unclear why Article $20 \mathrm{TFEU}$ should be interpreted as a residual ground of protection. National measures that are liable to hamper the use of this right could be captured by Article 21 TFEU. This puts into jeopardy the justification for having the substance of rights test. If all this test purports to do is protect citizens against deprivations of the right to move and reside freely, it would, for reasons of clarity, certainty, and soundness of legal argumentation, be better to abolish it and simply apply the right to free movement as laid down in Article 21 TFEU.

The remaining difficulty is that it is not evident that national measures that produce Ruiz Zambrano-type situations interfere with the right to move and reside freely. The Court has tried to support its arguments to this effect by underlining the importance of the right to residence. In Chavez-Vilchez, it argued that the individuals 'would have to leave the territory of the European Union, the consequence might be a restriction on the rights conferred on their children by their status as Union citizens, in particular the right of residence. ${ }^{61}$

$61 \quad$ Chavez-Vilchez (n 19), para 65. See also, Rendón Marín (n 26), para 78. 
Perhaps a plausible path forward would be to recognise that EU citizens have a right to reside within the territory of the Member States and that this right is breached if they are forced to leave the territory of the Union. This will depend on whether a plausible argument can be made that the right of residence is a right that EU citizens enjoy independent of the right to free movement. ${ }^{62}$ It might be that such a move would go beyond what the Member States agreed upon, in which case it might be impossible to salvage the substance of rights test. Yet if it can, it can be done under Article 21 TFEU. The Court needs neither to rely on the artificial distinction between Articles 20 and 21 TFEU nor the substance of rights test itself to protect the right of $\mathrm{EU}$ citizens to reside within the territory of the Union.

62 As suggested by, Opinion of AG Sharpston ( $\mathrm{n}$ 11), para 5 . 